\title{
COVID-19 Pandemisinin Ankara'da Toplu Taşım Kullanımına Etkisi
}

\author{
Hilal Tulan Işıldar ${ }^{1}$ \\ ORCID: 0000-0002-7922-3340
}

\author{
Ebru Vesile Öcalır² \\ ORCID: 0000-0001-8381-1308
}

Öz

COVID-19 salginının yayllması, dünyanın birçok ülkesinde seyahat, hareket ve aktivite katıllımın kıstllayan benzeri görülmemiş önlemlerin uygulanmasına neden olmuştur. Pandemi sürecinde dünya genelinde kent içi hareketlilik \%50-90 arasında azalırken bu oranının büyük kısmını toplu taşım kullanımı oluşturmaktadır. 2020 yılının Nisan ayında Avrupa ülkelerinde toplu taşım kullanımı oranında \%50-85, Asya ülkelerinde \%15-80, Afrika ülkelerinde \%10-70 ve ABD'de \%45-50 arasında düşüş yaşanmıştır. Türkiye'de ise COVID-19 pandemisi nedeniyle 16 Mart 2020'de başlayan kisttlamaların uygulanması ve 24 Mart 2020 tarihinde toplu taşıma araç kapasitesinin \%50'ye düşürülmesiyle Nisan 2020'de Türkiye'de hareketlilik $\% 75$ ve toplu taşım kullanımı \%60-73 azalmıştır. Ankara'da; Nisan 2020'de toplu taşım kullanımı \%87 azalmış ve ilk kez yolculuk türel ayrımında özel taşımın oranı \%50'nin üzerine çıkmıştır. Bu çalı̧̧mada COVID-19 pandemisinin Ankara'daki toplu taşım kullanımına etkisinin ortaya konulması amaçlanmaktadır. Bu kapsamda pandemi öncesi ve pandemi dönemi boyunca Ankara'da 1 iş günündeki kent içi ulaşım türlerinin yolculuk türel dağıllmları karşılaştırllmıştır. Pandemi süreci ve sonrasında Ankara'da toplu taşım kullanımını arttırıcı çözüm önerileri sunulmuştur.

Anahtar Kelimeler: COVID-19, hareketlilik, toplu taşıma, Ankara.

\footnotetext{
${ }^{1}$ Doktora Öğrencisi, Gazi Üniversitesi, E-mail: tulanhilal@gmail.com

2 Prof. Dr., Gazi Üniversitesi, E-mail: ebruocalir@gazi.edu.tr

idealkent @ Kent Araştırmaları Dergisi (Journal of Urban Studies) 


\title{
Impact of COVID-19 Pandemic on Public Transport Use in Ankara
}

\author{
Hilal Tulan Işıldar ${ }^{3}$ \\ ORCID: 0000-0002-7922-3340
}

\author{
Ebru Vesile Öcalır ${ }^{4}$ \\ ORCID: 0000-0001-8381-1308
}

\begin{abstract}
The spread of the COVID-19 pandemic has led to the implementation of unprecedented measures in many countries around the world that restrict travel, movement and activity participation. The urban mobility has decreased by 50-90\% throughout the world during the pandemic process, while the majority of this rate is the use of public transportation. In April 2020, the rate of public transport usage decreased by 50-85\% in European countries, 15-80\% in Asian countries, 10-70\% in African countries, and 45-50\% in the USA. In Turkey, due to the COVID-19 pandemic, implementation of restrictions starting on March 162020 and the reduction in public transport capacity to 50\% on March 24 2020, mobility in Turkey has decreased 75\% and the public transport use has decreased by 60-73\% in April 2020. Public transport use in Ankara decreased by 87\% in April 2020 and for the first time the share of private transport in modal split has increased to over $50 \%$. In this study, it is aimed to reveal the effect of COVID-19 pandemic on public transport usage in Ankara. In this regard, the modal distributions of urban transportation modes for 1 working day in Ankara, before and during the pandemic period, are compared. Solutions to increase the use of public transportation in Ankara, during the pandemic process and afterwards, are presented.
\end{abstract}

Keywords: COVID-19, mobility, public transportation, Ankara.

\footnotetext{
${ }^{3}$ PhD Student, Gazi University, E-mail: tulanhilal@gmail.com

4 Prof. Dr. Gazi University, E-mail: ebruocalir@gazi.edu.tr

idealkent (c) Kent Araştırmaları Dergisi (Journal of Urban Studies) 


\section{Giriş}

COVID-19 virüsü ilk kez Aralık 2019'da Çin'in Wuhan kentinde görülmüştür. Ocak 2020'de virüse COVID-19 tanısı konduğunda bile küresel felaketin boyutu anlaşılamamıştır. Çin'de başlayan salgın, küreselleşmenin de etkisiyle bir anda tüm dünyaya yayılmıştır. 11 Mart 2020'da Dünya Sağlık Örgütü (WHO) son iki hafta içerisinde Çin dışındaki vakaların 13 kat artması ve bulaşın görüldüğü ülke sayısının üçe katlanması, sonuçta 114 ülkede 118.000 'e ulaşan vaka sayısı ve o ana kadar ölümle sonuçlanan 4.291 vaka üzerine COVID-19 pandemisi ilan etmiştir (WHO, 2020).

COVID-19, oldukça bulaşıcı solunum patojenleri olan koronavirüs kategorisine aittir. COVID-19 virüsü en çok birbirine 2 m'den yakın olarak fiziksel ortamda bulunan kişilerin yakın temasıyla yayılmaktadır. COVID-19 virüsünü taşıyanlar öksürdüğ̈̈̈nde, hapşırdığında, şarkı söylediğinde, konuştuğunda veya nefes aldığında solunum damlacıkları üretirler. Bu damlacıkların boyutları, daha büyük damlalardan daha küçük damlacıklara kadar değişebilmektedir. Sağlıklı bir insan bu damlacıklara maruz kaldığında enfeksiyona yakalanma riski bulunmaktadır. Damlacıkları üreten kişiden ne kadar uzakta durulursa enfeksiyon riski de azalmaktadır (CDC, 2021).

Dünya'nın pandemiye tepkisi değişen oranlarda kapanma şeklinde olmuştur. Çalışma, eğitim, alışveriş ve sosyal yaşantı ile ilgili tüm aktiviteler kendini bu sürece uyumlamak durumunda kalmıştır. Eve kapanma, izolasyon, bir sıkılaşan bir gevşeyen tedbirler beraberinde değişen iş-eğitim-sosyalekonomik-ticari koşullara uyum sağlamada karşılaşılan psikolojik, toplumsal, ekonomik, çevresel ve teknik sorunları da getirmiştir. Sistem sağlık sektörü çalışanlarını zorlarken, ekonomideki sektörler arasında büyüyenler ve küçülenler belirmiştir. Kimi işyerleri tamamen evden yürütülen bir çalışma şeklini benimserken, kimileri daha esnek çalışma saatleri ya da işyerinde alınan tedbirlerle ekonomiden kopmamaya çalışmıştır. Teknolojinin de yardımıyla çevrimiçi eğitimin türlü çeşitleri denenmiştir. Market alışverişleri dâhil ticaretin önemli kısmı e-ticarete dönüşmüştür. Yazılım teknolojisi ve lojistik hiç olmadığı kadar ön plana çıkmıştır. Bu değişsimler küresel olarak tüm coğrafyalarda değişen oranlarda gözlenmiştir. Pandeminin birinci senesi dolmak üzereyken nihayet bulunan aşılar ise, çoktan mutasyona uğramış virüs karşısında istenildiği düzeyde etkili olamamıştır.

Ulaşım hizmeti, küreselleşen ve ticareti yapılan hizmetler arasında bulunmaktadır (UN, 2002). Bu tanım, bazı istisnalar dışında, bir ekonomide ikamet edenler tarafından bir başkası için gerçekleştirilen ve yolcuların taşınmasını, 
malların taşınmasını (yük), mürettebatla taşıyıcıların kiralanmasını (charter) ve ilgili destek ve yardımc hizmetleri içeren tüm ulaşım hizmetlerini kapsamaktadır (Öcalır Akünal ve Erol, 2016).

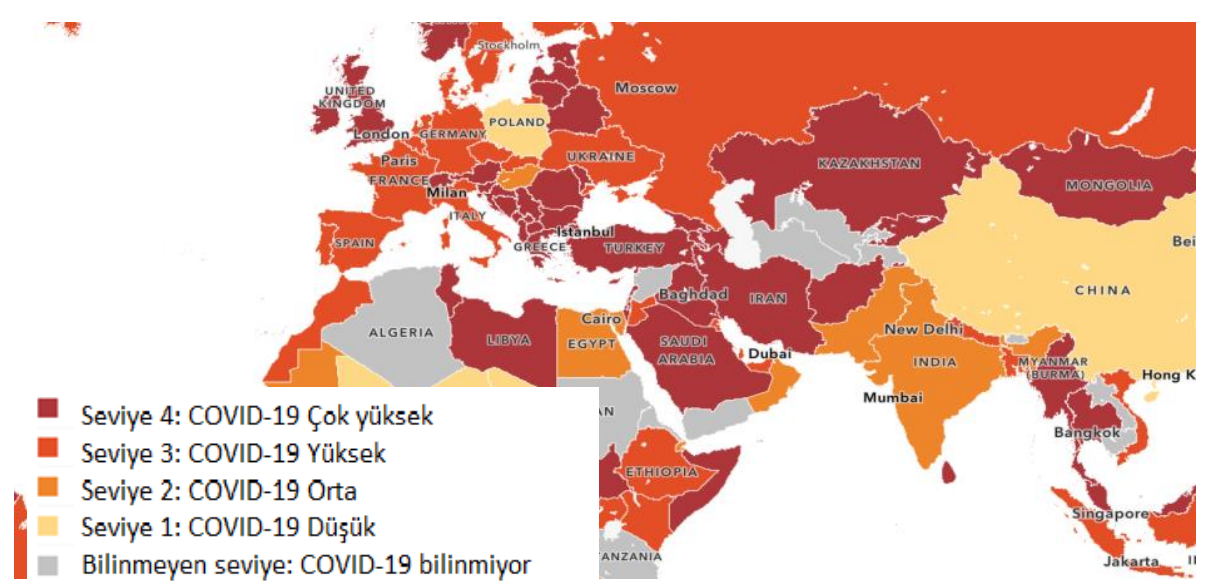

Şekil 1. Salgın Kontrol ve Önleme Merkezi (CDC)'ye göre ülkelerin COVID-19 süresince seyahat riski durumları (CDC, 2021)

Gelinen noktada, Salgın Kontrol ve Önleme Merkezi (CDC), ülkeleri 4 farklı risk seviyesi ve bir de bilinmeyen seviye ile tanımladığı bir haritayla takip etmektedir. Kırmızı ile gösterilen ve riskin en yüksek seviyede olduğu kabul edilen Seviye 4'teki ülkelere seyahatin tamamen önlenmesi, açık kırmızı ile gösterilen Seviye 3 riskli ülkelere gereksiz seyahatlerin önlenmesi, turuncu ile Seviye 2'deki riskli ülkelere kronik rahatsızlığı olan hastaların seyahat etmemesi ve sarı ile gösterilen Seviye 1'de riskli ülkelere seyahat edilecekse gerekli önlemlerin alınması tavsiye edilmektedir. Veri eksikliği yüzünden bilinmeyen olarak tanımlanan riskli ülkelere ise gerekmedikçe seyahat yapılmaması tavsiye edilmektedir. Türkiye bu haritada riskin en yüksek olarak kabul edildiği Seviye 3'te yer almaktadır.

Bu çalışmada; Ankara'da pandemi öncesi ve pandemi dönemi boyunca yolculuk türel dağılımındaki değişimler incelenerek; pandeminin toplu taşım kullanımına etkisinin ortaya konulması amaçlanmaktadır.

Çalışmanın bundan sonraki bölümü şu şekilde organize edilmiştir: Literatür taramasında COVID-19 pandemisinin; Dünyada ve Türkiye' de kent içi hareketliliğe ve toplu taşım kullanımına etkisi ortaya konulmuştur. Bu kapsamda toplu taşım kullanımını arttırıcı çalışmaların yapıldığı kentler ve yeni- 
likçi uygulamalar ele alınmıştır. Ankara'da pandemi öncesi ve pandemi dönemi boyunca her ayın ortalaması alınarak 1 iş günü yolculuk türel dağılımlarındaki değişim karşılaştırılmıştır. Elde edilen bulgular neticesinde pandemi dönemi ve sonrasında toplu taşımın yolculuk türel dağılımındaki payını arttırıcı çözüm önerileri sunulmuştur.

\section{Literatür Araştırması}

Küresel ve ticareti yapılan ulaşım hizmetinin, dünyanın neredeyse her yerine seyahatin önlenmesi ve/veya sinırlandırılmasının tavsiye edildiği bir süreçte, kent içi toplu taşımacılık sektörü de büyük ölçüde olumsuz yönde etkilenmiştir. Tam kapanma koşullarında bile zaruri ihtiyaçların karşılanması için ulaşım hizmetinin sağlanması zorunluluğu, kentlerde toplu taşım hizmetinin yeniden sorgulanmasına yol açmıştır. Toplu taşıma araçlarının virüsün yayılma ve bulaşma şekli için ideal bir ortam hazırlaması yönündeki inanış, ilk tepki olarak kullanıcıların her ne olursa olsun başka ulaşım türlerine yönelmesine yol açmıştır. Yolculuk talep seviyelerindeki dramatik düşüş, toplu taşıma hizmetlerinin öncelikle ele alınmasını gerektirmektedir. Bir taraftan hizmet kapasitesinin değişmesi diğer taraftan da zorunlu hizmetleri yerine getirmekle yükümlü çalışanları işyerlerine ulaştırma zorunluluğu toplu taşımla ilgili yeni düzenlemeler yapılmasını zorunlu kılmıştır (Gkiotsalitis ve Cats, 2020). Uluslararası Toplu Taşıma Derneği (UITP, 2020), özellikle yüksek riskli kullanıc grupları için güvenli mesafeyi sağlarken yolculuk talebindeki azalmaya rağmen yüksek hizmet seviyelerini yakalamaya çalışmayı toplu taşıma işletmelerinin karşılaştığı ana zorluklardan biri olarak görmektedir. Gerek üretim faaliyetlerinin durma seviyelerine gelmesi ya da üretim şekillerinin her gün işe gitmeyi gerektirmeyecek şekiller bulması gerekse toplu taşımaya gösterilen kolektif tepki, toplu taşımanın ücret toplama ile gelen gelirlerinin dünya genelinde bazı kentlerde \% 90'lara kadar azalmasına yol açmıştır. Kamu sağlığını korumak için yapılan ekstra dezenfeksiyon ve diğer maliyetler de işletmecilerin çözmesi gereken önemli problemlerdendir.

COVID-19 pandemisi sebebiyle, hükümetler ve yerel yönetimler virüsün yayılmasını engellemek için çeşitli önlemler almıştır. Önlemlerin çoğu, vatandaşların sosyal temaslarını en aza indirgemek üzerine geliştirilmiştir (Arellena vd, 2020). Bu sebeple; sosyal mesafe, yeni bir norm haline gelmiştir. Evde kalma politikası, okul, kamu kurumları ve işyerlerinin kapatılması, toplu etkinliklerin ve toplantıların iptali ve toplu taşımadaki kısıtlamalar dahil olmak üzere çeşitli katı politikalar dünya nüfusunun yaklaşık \%90'ını etkileyerek 
hareketlilikte genel bir azalmaya neden olmuştur (Gössling, vd, 2020). Günlük aktivitelerine pandemi öncesinde olduğu gibi devam eden yolcuların ise kentsel ulaşım türü tercihlerinde toplu taşıma ve araç paylaşımlarına zarar verecek şekilde değişiklikler yaşanmıştır. Artık kendilerini virüsten korumak adına daha fazla insan özel ulaşım yöntemlerini tercih etmektedir. Küresel çapta artan otomobil kullanımı; daha fazla enerji ve maliyet harcamasına, kentsel yayılmaya ve toplu taşım hizmetinde aksaklıkların yaşanmasına sebep olmaktadır (Koehl, 2020).

COVID-19 salgınının hareketlilik üzerinde önemli bir etkisi olmuştur. Dünyadaki ülke örneklerinde pandeminin yayılmasını yavaşlatmak için verilen en önemli kararlardan birinin insanların hareketliliğini kıstlamak olduğu görülmektedir. Bununla birlikte, ulaşımın azaltılması tüm ulaşım türlerini aynı oranda etkilememiştir. Pandemi döneminde toplu taşıma istasyonlarının ve araçlarının aşırı kalabalık olması ve böylece yüksek düzeyde bir bulaşma riski teşkil etmesi sebebiyle toplu taşıma kullanımında önemli düşüşler görülmüştür (Bucsky, 2020, s.1). Hükümetler ve yerel yetkililer de toplu taşım kullanımlarını sınırlandırmak için çeşitli kısıtlama önlemleri uygulamaktadır (Marcucci vd., 2020).

Dünya'da pek çok kent; toplu taşım araç kapasitesini sınırlandırmıştır. Tablo 1'de belirli bölgelerin toplu taşıma araç kapasiteleri verilmiştir. Örneğin; Milano ve Barselona toplu taşım maksimum doluluk oranlarını sırasıyla \%25 ve \%50'ye, Çin'in bazı kentleri ile İstanbul ve Ankara \%50'ye, İlanda ve Portekiz' in bazı kentleri sırasıyla \%20 ve $2 / 3^{\prime}$ e düşürme kararı almıştır. Yeni Güney Galler ve Avustralya' da ise toplu taşım kapasitesi sırasıyla 12 ve 32 yolcuya düşürülmüştür (Marcucci vd., 2020; Terrill, 2020).

Tablo 1. Pandemi döneminde bölgelerin toplu taşıma kapasitesi (Kaynak: Marcucci vd., 2020; Terrill, 2020)

\begin{tabular}{lc}
\hline Ülke ve kent adı & İzin verilen toplu taşıma kapasiteleri \\
\hline Milano & $\% 25$ \\
\hline Barselona & $\% 50$ \\
\hline İstanbul & $\% 50$ \\
\hline Ankara & $\% 50$ \\
\hline Çin'in belirli kentleri & $\% 50$ \\
\hline İrlanda'nun belirli kentleri & $\% 20$ \\
\hline Portekiz'in belirli kentleri & $2 / 3$ \\
\hline Yeni Güney Galler & 12 yolcu \\
\hline Avustralya & 32 yolcu \\
\hline
\end{tabular}


Dünyanın bazı metropollerinde pandemi tedbirleri kapsamında ulaşım arzında değişiklik örnekleri Tablo 2'de verilmiştir. Örneğin; Londra, Manchester, Washington, New York ve Amsterdam gibi metropollerde toplu taşım sefer sayıları ve kapasitelerinin azaltılması sebebiyle artan ulaşım talebini karşılamak için hükümet ve yerel yöneticiler tarafından tür değişikliği desteklenmektedir. Bu kapsamda New York City bisiklet paylaşım programı yolcu sayılarında pandemi öncesine göre \%67'lik bir artış yaşanmıştır. Bogota'da hükümet 76 km'lik geçici bisiklet yolları açmıştır. Paris ve Milano'da araba şeritlerinin bir kısmı bisiklet şeridi ve kaldırıma dönüştürülmüştür. Brüksel, insanları ilk sıraya koymak için bir hareketlilik planı uygulamıştır. Pentagon'da; kaldırımların, bisikletlilerin ve yayaların geçişine açıldığı ve otomobillerin hız sınırının $20 \mathrm{~km} / \mathrm{s}$ ye düşürüldüğü şehir merkezinin bir bölgesinde, kamusal alanın kullanım öncelikleri bisiklet ve yaya lehine değiştirilmiştir. Milano şehri, yürüyerek ve bisikletle harekete öncelik vermeyi amaçlayan açık sokaklar projesini yayınlamıştır. İsrail'in merkezinde belirlenen pilot bölgede akıllı işe gidiş-geliş projesiyle araç paylaşımı desteklenmiştir. Çin ve Singapur'da hükümet kararıyla yeni otomobil alımlarını engelleyici lisans kısıtlaması ve yol ücretlendirilmesi, San Diego'da yapay zekâ ile güçlendirilen mobilite çalışmaları yapılmıştır. Birleşik Krallık, Las Vegas ve San Francisco'da biletsiz mobil ödeme sistemi geliştirilmiştir. Londra'da; yaya hareketliliğini teşvik amaçlı metrolarda, 5-15 dk yürüme mesafelerinin rotalarını gösteren dijital paneller yer almaktadır. Pittsburg' da salgının yayılmasını önlemek için seyahat sürelerini kısaltıcı yapay zekâ ile çalışan trafik ışıkları kullanılmaya başlanmıştır. Edinburgh'da ise kısıtlamaların arttı̆̆ı s1rada özel ulaşım yerine aktif hareketliliğe öncelik tanıan; yürüyüş ve bisiklet için güvenli alanlar yaratma girişimi başlatılmıştır (Fishman vd., 2020; UITP, 2020).

Tablo 2. Dünyanın çeşitli metropollerinde pandemi tedbirleri kapsamında ulaşım arzında değişiklik örnekleri (Kaynak: Fishman vd., 2020; UITP, 2020)

\begin{tabular}{ll}
\hline Ülke ve kent adı & Yapılan değişiklikler \\
\hline New York City & Bisiklet paylaşım programı \\
\hline Bogota & 76 km'lik geçici bisiklet yolu \\
\hline Paris ve Milano & $\begin{array}{l}\text { Otomobil şeritlerinin bir kısmının bisiklet şeridi ve kal- } \\
\text { dırıma dönüştürülmesi }\end{array}$ \\
\hline Brüksel & $\begin{array}{l}\text { İsanların mobilitede ilk sırada yer alacağı hareketlilik } \\
\text { planı }\end{array}$ \\
\hline Pentagon & Şehir merkezinde otomobil hız sınırı 20 km/s olarak be- \\
& lirlenmesi \\
\hline Milano & Açık sokaklar projesi \\
\hline
\end{tabular}




\begin{tabular}{ll}
\hline İsrail'de belirlenen pilot bölgede & $\begin{array}{l}\text { Akıllı işe gidiş geliş projesiyle araç paylaşımının MaaS } \\
\text { uygulamasıla desteklenmesi }\end{array}$ \\
\hline Çin ve Singapur & $\begin{array}{l}\text { Yeni otomobil alımlarını engellemek için lisans kısıtla- } \\
\text { ması ve dinamik yol fiyatlandırma çalışmaları }\end{array}$ \\
\hline San Diego & Yapay zekâ ile güçlendirilmiş mobilite çalışmaları \\
\hline Birleşik Krallık'ta belirli bölgeler & Biletsiz mobilite kapsamında mobil ödeme yöntemi ge- \\
& liştirilmesi \\
\hline Las Vegas & Monoray yolcularının Google Pay ile bilet satın alabil- \\
& meleri \\
\hline San Francisco & 22 toplu taşıma acentesinin aldığı kararla mobil ödeme \\
& imkânı \\
\hline Londra & Yeni tasarım ilkesiyle metrolarda insanların 5-15 dk za- \\
& manlı yürüme rotalarının yer alması \\
\hline Pittsburgh & Seyahat süresini azaltmak için yapay zekâ ile çalışan tra- \\
& fik 1şıklarının kullanımı \\
\hline Edinburgh & Aktif hareketliliğe öncelik tanıyan yaya-bisiklet yolları \\
& için güvenli alanların oluşturulması \\
\hline
\end{tabular}

Bu gelişmelerin yanı sıra küresel bir salgın olan COVID-19 nedeniyle fiziksel mesafeyi garanti eden özel araç kullanımında ciddi artışlar Tablo 3'te görülmektedir. Budapeşte'de pandemi esnasında yolculuk türel dağılımında özel aracın payı \%43'ten \%65'e yükselmiştir (Marcucci vd., 2020, s.). Çin'de bazı kentlerde yolcular özel ulaşımı enfeksiyon riskini azaltmanın bir yolu olarak gördüğü için yolculuk türel dağılımında özel aracın payı \%34'ten \%66'ya yükselmiştir (Deloitte, 2020, s.9). İstanbul'da özel araç kullanımı pandemi öncesi \%15'ken pandemi döneminde \%54'e yükselmiştir (Moovit toplu taşıma endeksi, 2020). Ankara'da ise yolculuk türel dağılımında özel aracın payı \%39'dan \%58'e yükselmiştir F. Vural (kişisel iletişim, 4 Ekim 2021).

Tablo 3. Belirli bölgelerin pandemi dönemi ve öncesinde özel araç payının yolculuk türel dağılımındaki değişimi (Kaynak: Marcucci vd., 2020, Deloitte, 2020, s.9, Moovit toplu taşıma endeksi, 2020)

\begin{tabular}{llll}
\hline Ülke ve kent adi & $\begin{array}{l}\text { Pandemi öncesi özel } \\
\text { araç (\%) }\end{array}$ & $\begin{array}{l}\text { Pandemi dönemi özel } \\
\text { araç (\%) }\end{array}$ & \\
\hline Budapeşte & 43 & 65 \\
\hline Çin'in belirli kentleri & 34 & 66 \\
\hline İstanbul & 15 & 54 \\
\hline Ankara & 39 & 58 \\
\hline
\end{tabular}

Yeni fiziksel mesafe davranışları ve COVID-19 bulaşma korkusu nedeniyle toplu taşıma talebindeki keskin düşüş, alınan önlemler ve yapılan uygulamalara bağlı olarak değişiklik göstermekle birlikte şehirlerde özel araç kullanımını arttırmaktadır. Bu durum kent içi ulaşımda sürdürülebilirlik, erişilebilirlik, toplumsal eşitlik gibi küresel konularda risk teşkil etmektedir. 
Çünkü toplu taşıma yerel ekonominin bel kemiğidir. Sosyo-ekonomik gruplar arasında kentsel hareketliliği daha erişilebilir hale getirir. Aynı zamanda da çevresel adaleti sağlar. Bu sebeple; toplu taşıma kullanımını arttırıcı çalışmalar yapılmalıdır. Bu sayede toplu taşımanın; pandemi sonrasındaki koşullara güçlü bir şekilde geçiş yapması ve toplumsal rollerini yerine getirme yeteneğinin kazandırılması gerekmektedir (Triachini ve Cats, 2020, s.4).

\section{Metodoloji}

Bu araştırma şu araştırma sorularına cevap aramaktadır:

1. Türkiye'de pandemi döneminde kent içi hareketlilik konusunda alınan tedbirler dünya örnekleriyle örtüşmekte midir?

2. Ankara örneğinde pandemi döneminde kent içi ulaşım alışkanlıklarında değişim gözlenmiş midir?

3. Ankara örneğinde, yaşanan süreç kent içi ulaşımın sürdürülebilir geleceğinin yapısını oluşturmak için bir fırsata dönüştürülebilir mi?

Araştırma sorularının yanıtı 3 aşamalı bir çalışmayla araştırılmıştır:

1. Türkiye'de kent içi hareketliliği kısıtlayan hükümet tarafından alınan tedbirler ve kararların listelenmesi ve Dünya genelinde alınan tedbirlerle karşılaştırılması

2. Ankara' da pandemi öncesi ve sonrasında toplu taşıma ve özel taşıma yolculuklarının değişimine ait veri setinin analizinin yapılması ve türel ayrımdaki değişimin incelenmesi

3. Pandemi öncesi ve sonrası için değerlendirmelerde bulunulması ve öneriler geliştirilmesi

Veri seti olarak, Mart 2020- Ağustos 2021 tarihleri arasında Ankara kent içi ulaşım yolculuklarına ait veriler kullanılmıştır. Yolculuk alışkanlıkları, türel ayrımdaki değişimle karşılaştırılmıştır.

\section{Bulgular}

\section{Türkiye'de COVID-19 pandemisi kapsamında hükümet tarafindan alinan tedbirler}

Türkiye'nin sağlık otoritesi olan Sağlık Bakanlığı, salgın sürecinin başlaması ile birtakım tedbirler almıştır (Yücesan ve Özkan, 2020, s.135). COVID19 tanılı ilk vaka Türkiye Cumhuriyeti sınırları içerisinde 11 Mart 2020 tarihinde görülmüştür. Ancak Türkiye'de COVID-19'un pandemi ilan edilmesi 
beklenilmeden; hastalığın ülkeye yayılmasının engellenebilmesi adına kademeli olarak önlemler alınmaya başlanmıştır. Türkiye'de ilk vakanın görülmesinin hemen ardından ise alınan tedbirler oldukça sıkılaştırılmıştır. O günlerde hastalığın bir tedavi yöntemi ve aşısı olmadığı için hükümetin temel amacı salgının yayılım hızını kontrol altında tutabilmek olmuştur. Bu bağlamda Türkiye'de ilk vakanın görülmesinin ve salgının Dünya Sağlık Örgütü (DSÖ) tarafından pandemi olarak ilan edilmesinin ardından özellikle hareketliliği kısıtlayıcı tedbirlere Tablo 4 'te yer verilmiştir.

Tablo 4. Türkiye'de ve Dünya' da pandemi dönemi boyunca alınan tedbirler ve gelişmeler (Koyu renkler, tedbirlerde gevşetme veya tamamen kaldırmayı göstermektedir) (Kaynak: Cumhurbaşkanı Genelgesi No. 2020/4- 2021/13; Y1lmaz, 2020)

\begin{tabular}{|c|c|c|}
\hline Dünya'da Tedbirler ve Gelişmeler & Tarih & Türkiye'de Tedbirler ve Gelişmeler \\
\hline $\begin{array}{l}\text { Dünya Sağlı Örgütü (DSÖ) küresel salgın } \\
\text { (pandemi) ilan etti }\end{array}$ & 11.03 .2020 & Türkiye'de ilk vaka görüldü \\
\hline Almanya'da 14 eyalette okullar kapatildı & \multirow{2}{*}{13.03 .2020} & \\
\hline Çekya'da toplu taşıma hizmeti askıya alındı & & \\
\hline $\begin{array}{l}\text { DSÖ salgın merkezinin Avrupa olduğunu } \\
\text { duyurdu }\end{array}$ & \multirow{3}{*}{14.03 .2020} & \\
\hline ABD "ulusal acil durum" ilan etti & & \\
\hline İspanya'da bütün seyahatler iptal edildi & & \\
\hline \multirow[t]{8}{*}{$\begin{array}{l}\text { Fransa'da toplu taşımanın yalnızca açık işyer- } \\
\text { lerine hizmet vermesine karar verildi }\end{array}$} & 15.03 .2020 & \\
\hline & \multirow[b]{3}{*}{16.03 .2020} & Eğitime 3 hafta ara verildi \\
\hline & & Kütüphaneler kapatıldı \\
\hline & & $\begin{array}{l}\text { Sinema, konser, tiyatro, dügüun salonu, kafe- } \\
\text { terya, spor salonu gibi alanların faaliyetleri dur- } \\
\text { duruldu }\end{array}$ \\
\hline & 19.03.2020 & $\begin{array}{l}\text { Futbol, basketbol, voleybol ve hentbol ligleri er- } \\
\text { telenmiştir. }\end{array}$ \\
\hline & \multirow{2}{*}{21.03 .2020} & $\begin{array}{l}\text { Park, bahçe ve rekreasyon alanlarına giriş çıkış } \\
\text { yasağ getirildi }\end{array}$ \\
\hline & & $\begin{array}{l}65 \text { yaş ve üstü vatandaşlara sokağa çıkma yasağı } \\
\text { getirildi }\end{array}$ \\
\hline & $\begin{array}{l}21.03 .2020- \\
11.05 .2020\end{array}$ & Berber ve kuaförler kapatıldı \\
\hline \multirow[t]{2}{*}{$\begin{array}{l}\text { Hırvatistan'da } 30 \text { gün süreyle toplu taşıma } \\
\text { hizmeti askıya alındı }\end{array}$} & 22.03 .2020 & \\
\hline & $\begin{array}{l}22.03 .2020- \\
01.06 .2020\end{array}$ & $\begin{array}{l}\text { Kamu kurum ve kuruluşlarında esnek çalışma } \\
\text { saatlerine geçildi }\end{array}$ \\
\hline \multirow{4}{*}{2020 Tokyo Olimpiyatları 1 yıl ertelendi } & \multirow{2}{*}{24.03 .2020} & $\begin{array}{l}\text { Marketlerin müşteri kapasiteleri \%10'a düşü- } \\
\text { rüldü }\end{array}$ \\
\hline & & $\begin{array}{l}\text { Toplu taşıma yolcu kapasitesi \%50'ye düşü- } \\
\text { rüldü }\end{array}$ \\
\hline & 26.03 .2020 & Üniversitelerde uzaktan eğitime geçildi \\
\hline & 27.03 .2020 & Şehirler arası ulaşıma kısıtlama getirildi \\
\hline
\end{tabular}




\begin{tabular}{|c|c|c|}
\hline & 28.03 .2020 & $\begin{array}{l}\text { Havayolunda iç hat seferlerine kısıtlama geti- } \\
\text { rildi }\end{array}$ \\
\hline & \multirow{2}{*}{ 29.03.2020 } & $\begin{array}{l}\text { İstanbul, Ankara ve İzmir'de taksi plakalarına } \\
\text { tek-çift uygulaması getirildi }\end{array}$ \\
\hline & & $\begin{array}{l}\text { Ankara'da yaşayan } 18 \text { yaş altı vatandaşların } \\
\text { marketlere giris çıkıs yasağ getirildi }\end{array}$ \\
\hline $\begin{array}{l}\text { BM'den yapılan açıklamada insanlığın İkinci } \\
\text { Dünya Savaşı'ndan beri yaşadığı en büyük } \\
\text { kriz ile karşı karşıya olduğu bildirildi }\end{array}$ & 30.03 .2020 & \\
\hline \multirow[t]{6}{*}{$\begin{array}{l}\text { DSÖ, Ortadoğu ülkelerinin aldığı önlemleri } \\
\text { genişletmesini istedi }\end{array}$} & 2.04 .2020 & \\
\hline & \multirow{3}{*}{3.04 .2020} & $\begin{array}{l}20 \text { yaş altı vatandaşlara sokağa çıkma yasağı ge- } \\
\text { tirildi }\end{array}$ \\
\hline & & $\begin{array}{l}30 \text { büyükşehir ve Zonguldak'a giriş-çıkışlar dur- } \\
\text { duruldu }\end{array}$ \\
\hline & & $\begin{array}{l}\text { Istanbul ve Ankara'daki toplu taşımada maske } \\
\text { kullanma zorunluluğu getirildi }\end{array}$ \\
\hline & 5.04 .2020 & $\begin{array}{l}\text { Google'ın yayınladığı raporda göre Türkiye'de } \\
\text { mobilitenin } \% 75 \text { azaldığını bildirdi }\end{array}$ \\
\hline & 11.04 .2020 & $\begin{array}{l}30 \text { büyükşehir ve Zonguldak'ta } 48 \text { saat sokağa } \\
\text { çlkma yasağı ilan edildi }\end{array}$ \\
\hline \multirow[t]{7}{*}{ Fransa Bisiklet Turu ertelendi } & 15.04 .2020 & \\
\hline & 16.04 .2020 & $\begin{array}{l}\text { Hafta sonları } 30 \text { büyükşehir ve Zonguldak'ta so- } \\
\text { kağa çıkma yasağı ilan edildi }\end{array}$ \\
\hline & $\begin{array}{l}23.04 .2020- \\
26.04 .2020\end{array}$ & $\begin{array}{l}\text { Türkiye'nin tüm illerinde sokağa çıma yasağı } \\
\text { ilan edildi }\end{array}$ \\
\hline & $\begin{array}{l}01.05 .2020- \\
03.05 .2020\end{array}$ & $\begin{array}{l}\text { Türkiye'nin tüm illerinde sokağa çıkma yasağı } \\
\text { ilan edildi }\end{array}$ \\
\hline & 4.05 .2020 & $\begin{array}{l}65 \text { yaş üstü ve } 20 \text { yaş altı vatandaşlara günde } 4 \\
\text { saat sokağa çıma izni verildi }\end{array}$ \\
\hline & 10.05 .2020 & $\begin{array}{l}65 \text { yaş üstü vatandaşlara günde } 6 \text { saat dişarı } \\
\text { çlkma izni verildi }\end{array}$ \\
\hline & 11.05 .2020 & $\begin{array}{l}\text { Berber, kuaför ve AVM'ler yeniden hizmete } \\
\text { açlld }\end{array}$ \\
\hline \multirow[t]{6}{*}{$\begin{array}{l}\text { Fransa'da toplu taşımada maske kullanma zo- } \\
\text { runluluğu getirildi }\end{array}$} & 12.05 .2020 & \\
\hline & $\begin{array}{l}23.05 .2020- \\
26.05 .2020\end{array}$ & $\begin{array}{l}\text { Türkiye'nin tüm illerinde sokağa çkma yasağı } \\
\text { llan edildi }\end{array}$ \\
\hline & \multirow[t]{3}{*}{1.06 .2020} & $\begin{array}{l}\text { Tüm şehir içi toplu taşıma araçlarında \%50 ka- } \\
\text { pasite ile yolcu taşıma kararının iptal edilme- } \\
\text { sine, ancak ayakta yolculuğun kısıtlanmasına } \\
\text { karar verildi }\end{array}$ \\
\hline & & Sehirler arası seyahat kısıtlaması kaldırıldı \\
\hline & & $\begin{array}{l}\text { Kamu kurum ve kuruluşlarında esnek çalışma } \\
\text { sona erdi }\end{array}$ \\
\hline & 3.06 .2020 & $\begin{array}{l}65 \text { yaş üstü ve } 20 \text { yaş altı vatandaşlara getirilen } \\
\text { sokağa çıkma yasağı kaldırıldı }\end{array}$ \\
\hline $\begin{array}{l}\text { Birleşik Krallık'ta toplu taşımada maske kul- } \\
\text { lanma zorunluluğu getirildi }\end{array}$ & 15.06 .2020 & \\
\hline
\end{tabular}




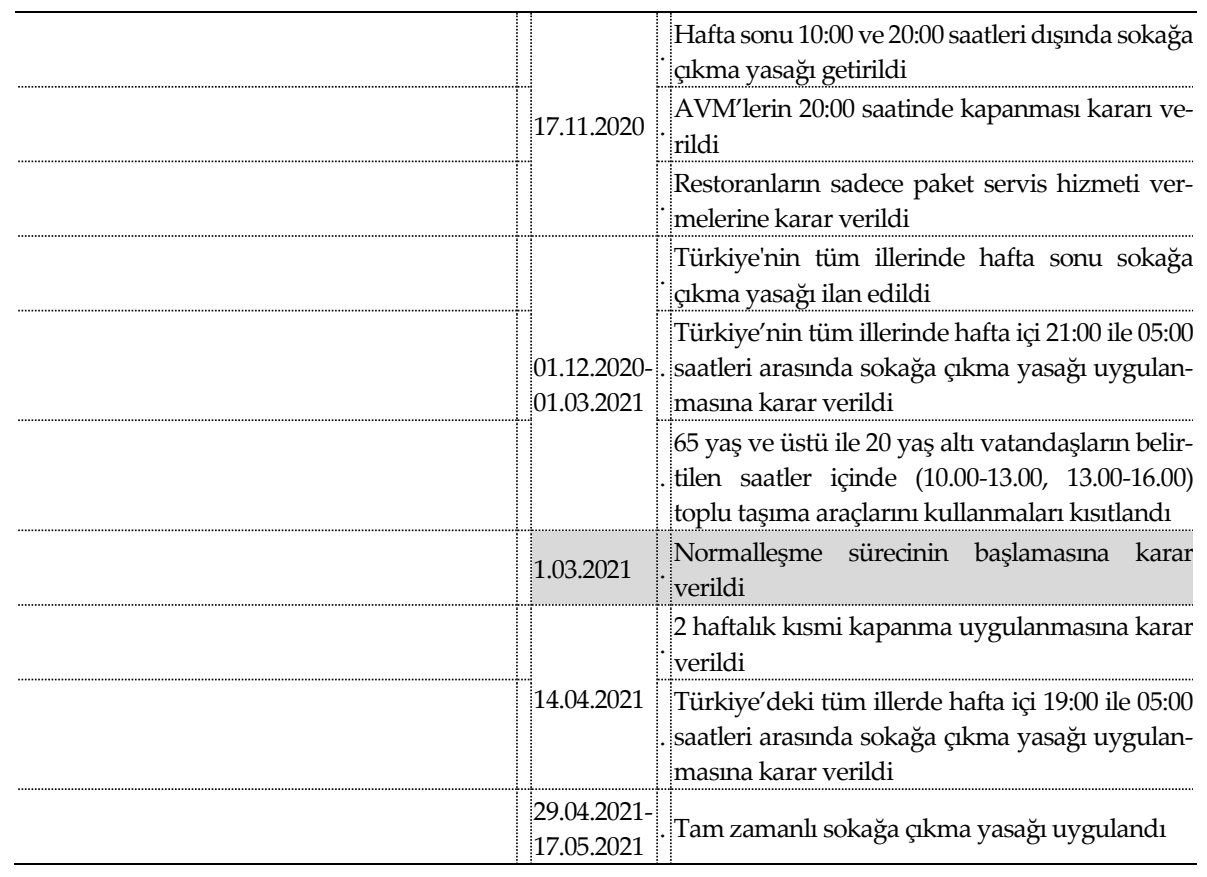

\section{COVID-19 pandemisinin Ankara kent içi ulaşımına etkisi}

Ankara'da, pandemiyle mücadele çerçevesinde toplu ulaşım alışkanlıklarını etkileyen bir dizi tedbirler alınmıştır ve uygulanmaya konulmuştur. İl Umumi Hıfzıssıhha Kurulları kararlarıyla yolcu kapasiteleri sınırlandırılmış, araçlar düzenli olarak dezenfekte edilmiş, nakitsiz ödeme sistemleri yaygınlaştırılmış, maske ve sosyal mesafe kuralları getirilerek vatandaşların sağlık ve güvenle seyahat etmesi sağlanmıştır. Ancak alınan tüm bu tedbirler toplu taşıma sektörünün gelirlerinde azalmaya giderlerinde büyük artış yaşanmasına neden olmuştur. Salgın kaynaklı vatandaşların toplu taşımaya güveninin azalması, özel araç kullanımı gibi diğer alternatiflere yönelmesi nedeniyle pandemi öncesi döneme göre toplu taşım yolcu sayısında azalma yaşanmaktadır. Ayrıca toplu taşıma araçlarında sosyal mesafe uygulamasının devam etmesi nedeniyle araçlarda taşıma kapasitesi tam olarak kullanılamamaktadır.

Ankara'da pandemi öncesi ve pandemi döneminde toplu taşıma ve özel taşıma yolculuklarındaki değişimin ve türel dağılımın belirlenebilmesi için yolcu sayılarına ait veri seti oluşturulmuştur. Tablo 5 'te pandemi öncesi 3 Mart 2020 tarihindeki 1 iş günü yolcu sayıları, pandemi dönemi boyunca ise Nisan 2020'den Ağustos 2021'e kadar her bir ay için 1 iş günü yolcu sayılarının ortalaması belirlenmiştir. Koyu renkli sütunlar, Tablo 4'e göre pandemi 
tedbirlerinin azaltıldığı veya tamamen kaldırıldığı dönemleri ifade etmektedir.

11 Mart 2020 tarihinde ilk vakanın görülmesi ve nisan ayına kadar toplu aktivitelere getirilen kısıtlamalar neticesinde; Tablo 5'e göre, pandemi öncesi 3 Mart 2020 tarihindeki yolculuk sayılarına göre Nisan 2020 ortalama yolculuk sayılarında yaklaşık \%79'luk bir azalma yaşandığı görülmektedir. Pandemi öncesine göre değerlendirildiğinde Nisan 2020'de toplu taşıma yolculuk sayılarında yaklaşık \%83'lük, özel taşıma yolculuk sayılarında ise yaklaşı \% 74'lük bir azalma olduğu görülmektedir. Toplu taşıma türlerine göre değerlendirildiğinde; pandemi öncesi 3 Mart 2020'ye göre nisan ayında en fazla azalma yaklaşı \% \%4 ile hafif raylı sistem olan Ankaray'da olurken, ikinci sırada ise yaklaşık \%89 ile metroda yaşanmıştır. Toplu taşımada yaşanan bu düşüşteki önemli etkenlerden bir diğeri ise 24 Mart 2020 tarihinde toplu taşıma kapasitelerinin \%50'ye düşürülmesi olarak değerlendirilebilir.

1 Haziran 2020'de kısıtlamaların kademeli olarak kaldırılmasıyla pandemi öncesine göre yolculuk sayılarındaki azalma oranlarında düşüşler yaşandığı görülmektedir. Haziran 2020'de Ankara'da 1 iş günü ortalama yolculuk sayısında 3 Mart 2020'ye göre \%38,5'lik bir azalma yaşanmıştır. Aynı tarihlere göre toplu taşıma yolculuk sayısında yaklaşık \%63, özel taşıma yolculuk sayısında ise yaklaşık \% $7^{\prime}$ lik bir azalma yaşanmıştır. Bu durum bulaşma riski korkusu sebebiyle yolculukların büyük kısmının özel taşıma tercih ettiğini göstermektedir (Tablo 5).

Vaka sayılarında yaşanan artış sebebiyle 17 Kasım 2020 ve 1 Aralık 2020 tarihlerinde tedbirler sıkılaştırılmış, hafta içi ve hafta sonu sokağa çıkma k1sttlamaları getirilmiştir. Bu durumun etkileri Tablo 5'e göre değerlendirildiğinde; pandemi öncesine göre Kasım 2020'de Ankara'da ortalama 1 iş günü yolculuk sayısı yaklaşık \%28, toplu taşım yolculuk sayısı yaklaşık \%52 azalırken, özel taşıma yolculuk sayısı \%2 artmıştır. Ankara'da pandemi öncesine göre günlük hareketlilikte hala azalma görülürken özel taşımın artış göstermesi toplu taşım yolcularının bir kısmının özel taşımayı tercih etmesiyle açıklanabilir. 


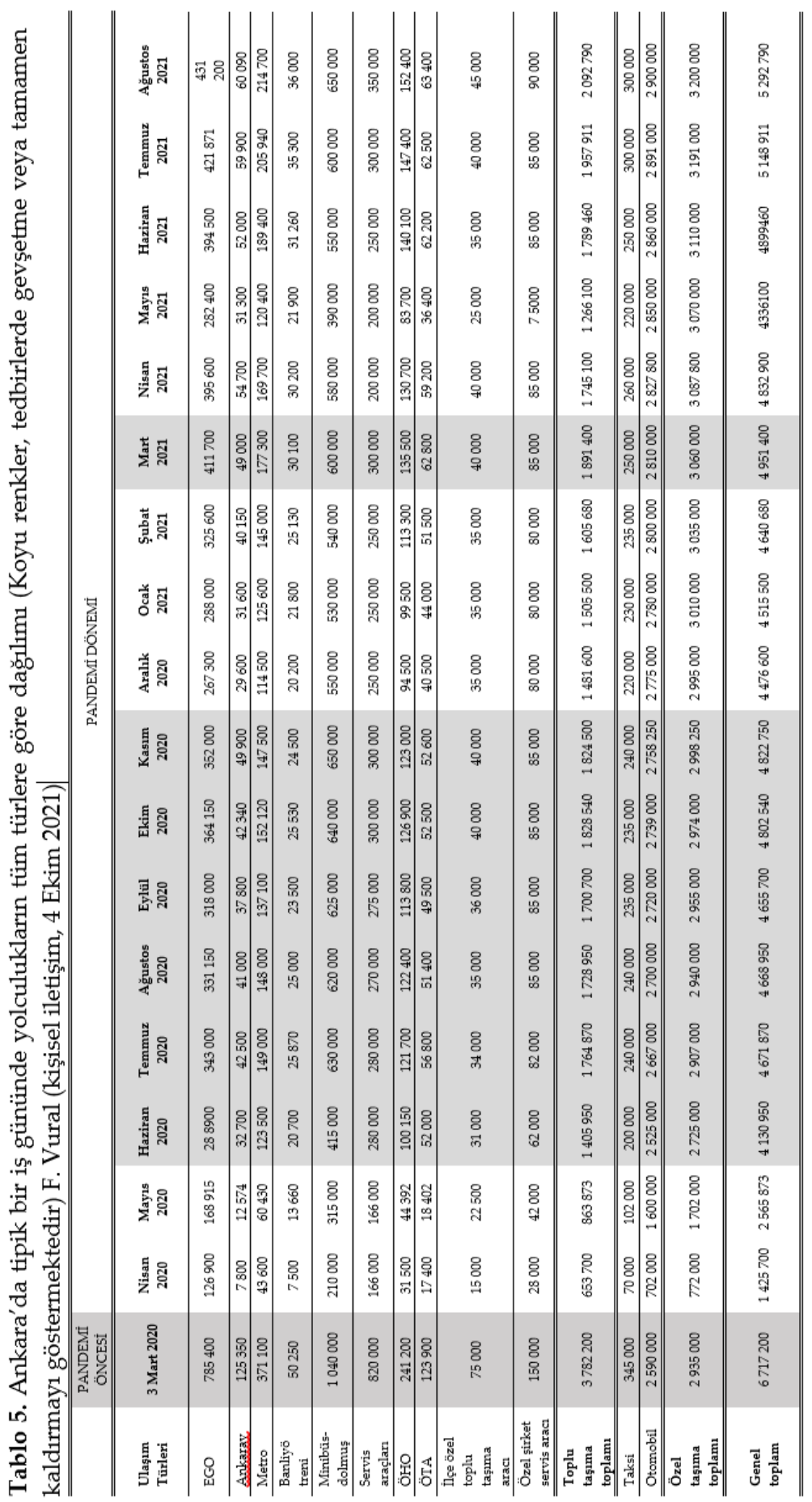




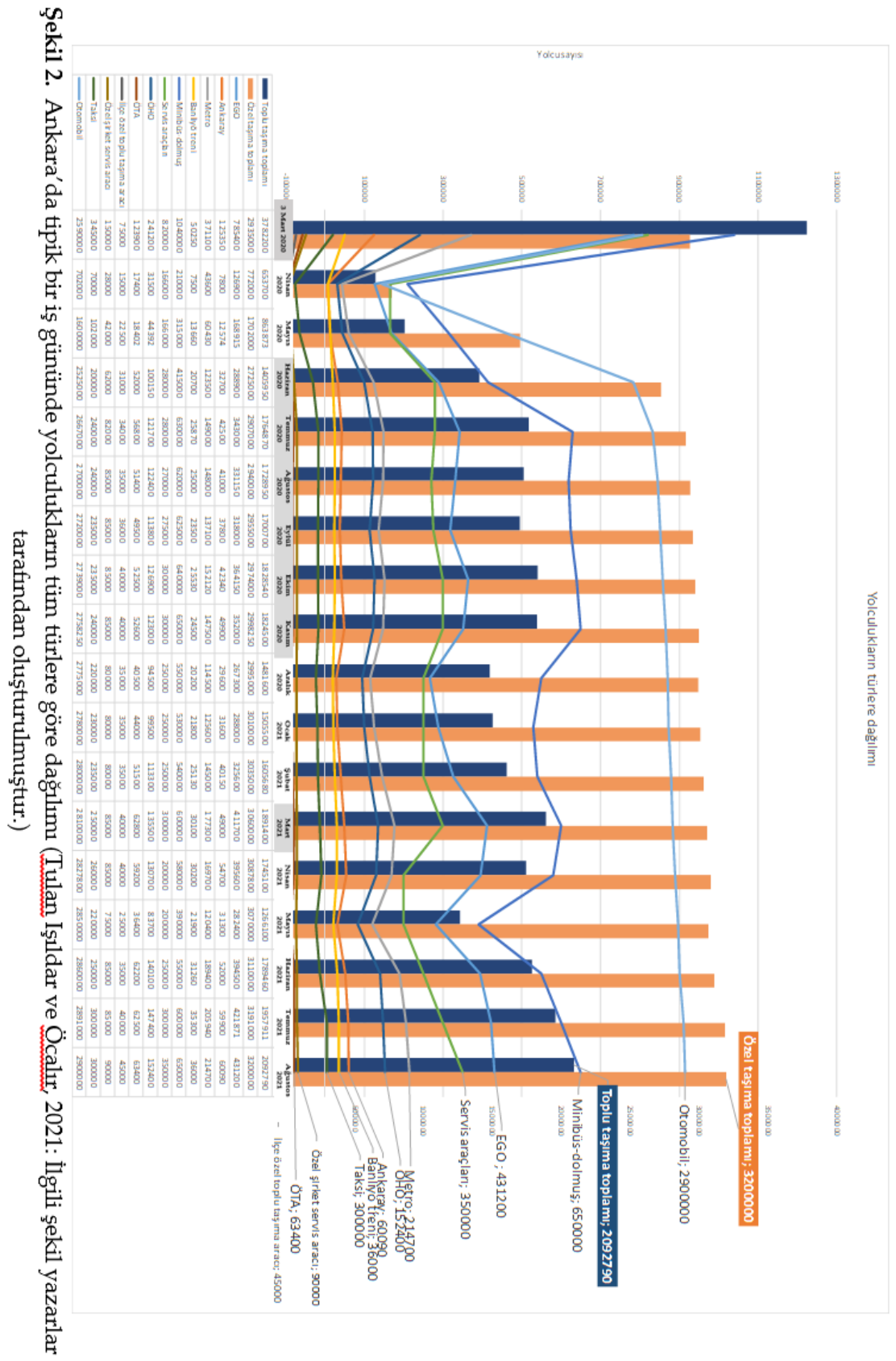

Pandemi ilan edilmesi ve tedbirlerin uygulanması üzerinden geçen 1 yılın sonunda Ankara kent içi ulaşım yolculuk durumu değerlendirildiğinde; 
Mart 2021'de pandemi öncesine göre Ankara ortalama 1 iş günü yolcu say1sında yaklaşık \%26 düşüş yaşandığı görülmektedir. Aynı tarihlere göre; toplu taşıma yolcu sayısında \%50 düşüş, özel taşıma yolcu sayısında \%4 artış yaşanmıştır. Pandemi öncesine göre; kısıtlamaların kaldırıldığı Ağustos 2021'de toplam yolcu sayısında \%21 düşüş yaşandığı görülmektedir. Aynı tarihlere göre; toplu taşıma yolcu sayısında yaklaşı \%45 düşüş, özel taşıma yolcu sayısında yaklaşık \%9 artış yaşandığı görülmektedir.

Ankara'da tipik 1 iş gününde yolculukların tüm türlere göre dağılımına ilişkin grafik Şekil 2'de verilmiştir. Ankara 1 iş günü toplu taşıma toplam yolculuk durumunun pandemi öncesi ve pandemi süresindeki değişimi Şekil 2'ye göre değerlendirildiğinde; pandemi öncesine göre belli aylarda değişiklik görülmesiyle beraber toplu taşıma kullanımında keskin düşüş yaşanmıştır. Ankara'da pandemi sebebiyle uygulanan tedbirler, toplu taşım kapasitesinin azaltılması, kamuoyunda toplu taşıma kullanımının salgın riskini arttırdığına yönelik çıkan haberlerin yarattığı tedirginlik, evden çalışma, uzaktan eğitim gibi günlük hareketliliğin azalması toplu taşıma kullanımının azalmasına sebep olmuştur. Pandeminin ilan edilmesinin ardından Nisan 2020'ye kadar özel taşıma kullanımında azalma yaşanmış sonraki süreçte ise artış yaşanmıştır.

Tablo 5 ve Şekil 2 birlikte değerlendirildiğinde, kısıtlama günlerinde toplu taşımın neredeyse durma noktasına geldiği, kısıtlamalar gevşedikçe toplu taşımanın da arttığını göstermektedir. Otomobil kullanımı, tedbirlerin ilk defa gevşemeye başladığı Haziran 2020'den sonra sürekli ve düzgün bir artış göstermiştir. Ankara örneğinde, ilk şokun ardından otomobil kullanıcılarının kendini duruma daha çabuk uyumladığını, toplu taşım kullanıcılarının ise koşullara karşı çok kırılgan olduğunu göstermektedir.

\section{COVID-19 pandemisinin Ankara'da yolculuk türel dağılımına etkisi}

Ankara kent içi ulaşımında pandemi öncesi 3 Mart 2020 tarihi ve pandemi süresinde Nisan 2020'den Ağustos 2021'e kadar yolculuk türel dağılımları Tablo 6'da verilmiştir. Pandemi dönemi öncesinde Ankara' da yolculuk türel dağılımında toplu taşımanın payı özel taşımadan fazlayken bu durumun pandemi süresinde tam tersi olduğu görülmektedir. Ankara'da kent içi hareketliliğin en düşük olduğu Nisan 2020'de özel taşımanın payı \%54,1 olup, bazı dönemlerde bu payda azalma olmasına rağmen Ağustos 2021'e kadar özel taşıma payının pandemi öncesi ve Nisan 2020'ye göre artış gösterdiği görülmektedir. 
Tablo 6. Ankara kent içi ulaşımı pandemi öncesi ve pandemi süresinde yolculuk türel dağılımı (Koyu renkler, tedbirlerde gevşetme veya tamamen kaldırmayı göstermektedir) F. Vural (kişisel iletişim, 4 Ekim 2021)

\begin{tabular}{lll}
\hline & Toplu taşıma (\%) & Özel taşıma (\%) \\
\hline 3 Mart 2020 & 56,4 & 43,6 \\
\hline Nisan 2020 & 45,9 & 54,1 \\
\hline Mayis 2020 & 33,7 & 66,3 \\
\hline Haziran 2020 & 34 & 66 \\
\hline Temmuz 2020 & 37,8 & 62,2 \\
\hline Ağustos 2020 & 37 & 63 \\
\hline Eylül 2020 & 36,5 & 63,5 \\
\hline Ekim 2020 & 38,1 & 61,9 \\
\hline Kasım 2020 & 37,8 & 62,2 \\
\hline Aralık 2020 & 33,1 & 66,9 \\
\hline Ocak 2021 & 33,3 & 66 \\
\hline Şubat 2021 & 34,6 & 65,4 \\
\hline Mart 2021 & 39,7 & 60,3 \\
\hline Nisan 2021 & 36,1 & 63,9 \\
\hline Mayis 2021 & 29,2 & 70,8 \\
\hline Haziran 2021 & 36,5 & 63,5 \\
\hline Temmuz 2021 & 38 & 62 \\
\hline Ağustos 2021 & 39,5 & 60,5 \\
\hline
\end{tabular}

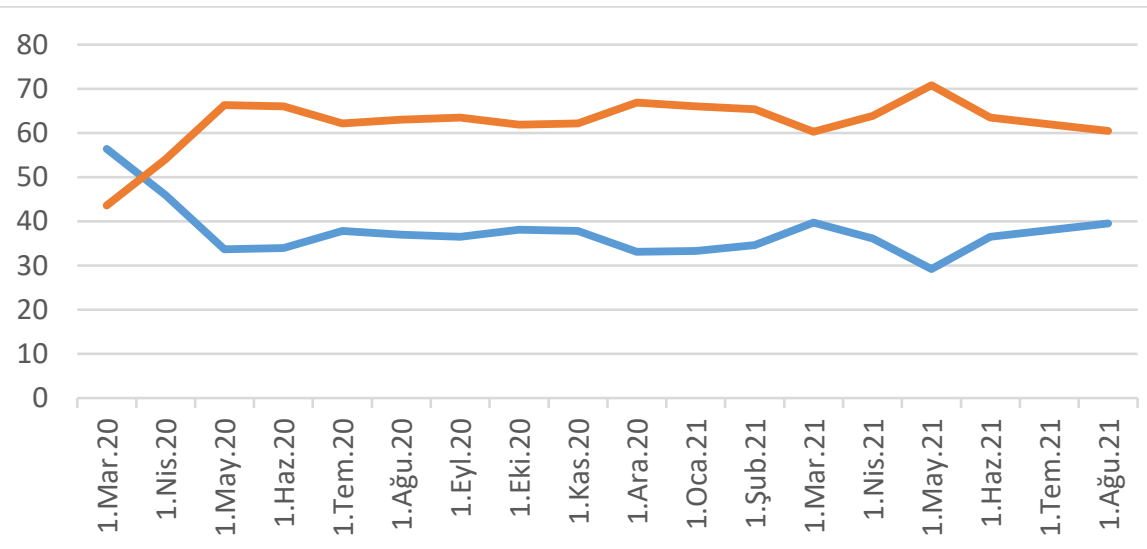

—Toplu taşıma türel dağılım —Özel taşıma türel dağılım

Şekil 3. Ankara kent içi ulaşımı pandemi öncesi ve pandemi süresinde yolculuk türel dağ1lımı değişimi (Tulan Işıldar ve Öcalır, 2021: İlgili şekil yazarlar tarafından oluşturulmuştur.)

Ankara'da pandemi öncesinde otomobilin yolculuk türel dağılımındaki pay1 \%38'ken bu oran pandemi sürecinde her geçen gün artış göstermiştir. Ağustos 2021'de Ankara'da 1 iş gününde yapılan yolculukların \%55'inin tek başına otomobile ait olduğu Şekil 4 'te görülmektedir. 


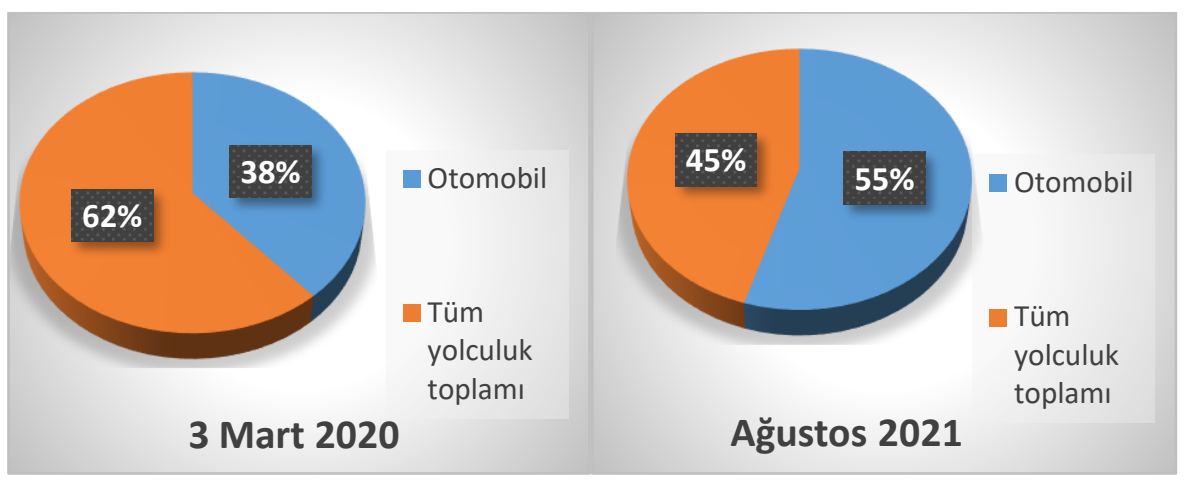

Şekil 4. Ankara' da pandemi öncesinde ve Ağustos 2021'de yolculuk türel dağlımında otomobilin payı (Tulan Işıldar ve Öcalır, 2021: İlgili şekiller yazarlar tarafindan oluşturulmuştur.)

Ankara'da; 2020 yılı 1000 kişiye düşen özel araç sayısı 1 yılda \%6,6 artışla 280 olmuştur. Halbuki 1 yılda nüfus yalnızca \%0,43 artmıştır. Çalışmada elde edilen bulgular bu artışın sebebini açıklamaktadır. Pandemi dönemi boyunca Ankara' da günlük hareketlilik; sokağa çıkma yasakları, evden çalışma, kamu kurumlarında esnek çalışma, uzaktan eğitim, zorunlu karantina, farklı yaş gruplarına özel daha sıkı tedbirler gibi sebeplerde pandemi öncesine göre azalmıştır. Pandemi dönemi boyunca hem toplam yolcu sayısı hem de toplu taşıma kullanan yolcu sayılarında belli aylarda tedbirlerin sıkılaştırılması veya esnetilmesine bağlı olarak dalgalanmalar yaşansa da pandemi öncesi 3 Mart 2020'deki günlük yolculuklara göre azalma yaşanmıştır. Ancak özel taşım yolcu sayısında pandemi öncesine göre Nisan-Mayıs-Haziran 2020 d1şında azalma görülmemiştir. Özel taşıma yolculuklarında ise taksi kullanıminda belirgin bir düşüş görüldüğü için bu yolculuklardaki değişim doğrudan otomobil kullanımıyla ilgilidir. Haziran 2020'den Ağustos 2021'e kadar otomobil yolcu sayısı pandemi öncesine göre artış göstermiştir. Bu da Ankara'da ilk kez yolculuk türel dağllımında özel taşımın payının toplu taşım payın geçmesini açıklamaktadır. Azalan hareketliliğe rağmen otomobil kullanımındaki artışın toplu taşım kullanan yolcuların tercih değişikliğinden kaynaklandığı görülmektedir.

\section{Sonuç ve Öneriler}

Pandemi öncesinde, ulaşım tercihlerine yönelik araştırmalar ve çalışmalar kentsel alanlarda sürdürülebilir ulaşıma odaklanmıştır. Kent içi ulaşım planlaması öncelikle enerji tüketimi, hava kirliliği gibi olumsuz çevresel sorunları 
en aza indirmek için en az sayıda araçla yolcu hacmini en üst düzeye çıkarmaya odaklanmıştır. Hareketlilik ve ulaşımda sürdürülebilirliği sağlamak için öncelikli olarak toplu taşım kullanımı teşvik edilmeye çalışılmıştır. Ulaşım sistemi planlaması için temel faktörler, seyahat talebinin değişkenliği ve toplu taşıma hattının hizmet düzeyi olarak kabul edilmiştir. Ancak bu dinamikler pandemi sırasında büyük ölçüde değişmiştir ve toplu taşım kullanımına yönelik kazanımlar da büyük ölçüde kaybedilmiştir. Bu değişimler kentlerdeki ulaşım alışkanlıklarına bağlı olarak farklılık göstermektedir. Örneğin; toplu taşım odaklı kentlerde yaya ve bisiklet kullanımını arttırıcı çözüm önerileri geliştirilirken toplu taşım yolculuklarını azaltma politikası izlenmektedir. Dikkat edilmesi gereken asıl değişim ise özel araç bağımlılığının halihazırda yüksek olduğu kentlerde gözlenmektedir.

Küresel ve ticareti yapılan ulaşım hizmetinin, dünyanın neredeyse her yerine seyahatin önlenmesi ve/veya sınırlandırılmasının tavsiye edildiği bir süreçte, kent içi toplu taşımacılık sektörü de büyük ölçüde olumsuz yönde etkilenmiştir.

Tam kapasite hizmet verdiğinde, toplu taşıma; ulaşım kaynaklı çevre kirliliği, enerji tüketimi, trafik sıkışıklığı, zaman kaybı, kentsel yayılma, sosyal adaletsizlik gibi problemleri azaltmakta ve ulaşımda sürdürülebilirliği sağlamaktadır. Ancak küresel bir salgın olan COVID-19 pandemisi sebebiyle toplu taşıma için oluşturulan hedef ve beklentilerde keskin değişimler yaşanmaktadır. Toplu taşıma araçlarında kapasitenin düşürülmesi, maske kullanma zorunluluğu, araç içi hijyen gibi konular bir anda temel öncelik haline gelmiştir. Salgın kaynaklı yaşanılan tedirginlik, toplu taşım hizmetleriyle ilgili hükümetlerin aldığı kısıtlayıcı kararlar, medyada çıkan olumsuz haberler gibi sebeplerle; toplu taşıma kullanan yolcuların büyük bir kısmı yüksek maliyetlere rağmen özel araç kullanmaya başlamıştır.

Pandemi dönemi boyunca gözlenen yolculuk alışkanlıklarındaki bu değişimin etkilerinin pandemi sonrası dönemde de devam etmesi durumunda Ankara'nın kent içi ulaşımı sürdürülemez bir noktaya gelecektir. Bu sebeple Ankara kent içi ulaşımında toplu taşım kullanımını arttırıcı çözüm önerileri şu şekildedir:

- Gelişmiş teknolojili yeni hizmetlere yatırım yapılarak hem halk sağlığının korunması hem de toplu taşım kullanımını teşvik edici çalışmaların yapılması (biletsiz mobil ücret ödeme, yapay zekâ ile çalışan seyahat süresini azaltan trafik ışıkları, toplu taşıma araçları ve istasyonlarında temassız ateş ölçümü, maske algılamasının sağlanacağı yapay zekâ teknikleri) 
- Otomobil alımını kısıtlayıcı uygulamaların yürürlüğe konulması

- Pandemi döneminin firsata çevrilerek kent merkezine otomobil ile girişin sınırlandırılması, yaya öncelikli hareketlilik planlarının hazırlanması

- Bu doğrultuda kent merkezine bağlanan belli akslarda otomobil şeritlerinden birinin yaya ve bisikletlilerin kullanımına açılması

- Mikro hareketlilik türlerinin (bisikletler, e-bisikletler, e-scooterlar, elektrikli kaykaylar, paylaşımlı bisikletler ve elektrikli pedal destekli bisikletler) desteklenmesi

- 'Trampe bisiklet asansörü' nün eğimin fazla olduğu bölgelerde uygulamaya geçirilmesi şeklindedir.

Not: Çalışmada kullanılan veriler, EGO'nun veri tabanından alınmıştır. Yazarlar, Şehir Plancısı Fuat Vural'a katkıları için minnettardır. 


\section{Extended Abstract}

\section{Impact of COVID-19 Pandemic on Public Transport Use in Ankara}

\author{
Hilal Tulan Işıldar \\ ORCID: 0000-0002-7922-3340
}

*

\author{
Ebru Vesile Öcalır \\ ORCID: 0000-0001-8381-1308
}

Considering the COVID-19 pandemic; not as a direct threat to public transportation vehicles but as an opportunity to change "private vehicle addiction" behavior makes urban mobility accessible to everyone. In the study, based on the change in Ankara travel modal split before and during the pandemic period; it is aimed to reveal the effect of the pandemic on public transportation usage in Ankara. In Ankara, which ranks first in private vehicle use, this rate is increasing with the effect of the pandemic; in order to prevent this situation, it is aimed to increase the share of public transportation in the travel modal split by benefiting from the studies of cities that have developed new mobility solutions to increase the use of public transportation and have achieved success. In the literature review, the effect of the COVID-19 pandemic in urban mobility and public transport use in Turkey and the world and the cities in which studies that were made to increase public transport use and practices of innovative solutions will be discussed. In Ankara, the average of each month will be taken before and during the pandemic period, and the change in the travel modal split will be compared for 1 working day.

As a result of the findings, solutions will be presented to increase the share of public transportation in the travel modal split during and after the pandemic period.

The COVID-19 outbreak has had a significant impact on mobility. One of the most important decisions made by countries around the world to slow the spread of the pandemic has been to restrict the mobility of people who have a significant impact on transport systems. However, the reduction in 
transport does not affect all modes of transport equally. The biggest ever decrease in public transport has been seen during the pandemic. Because; the overcrowding of public transport stations and vehicles poses a high risk of contamination. For this reason, governments and local authorities have implemented restraining measures to limit the use of public transport. Many cities in the world has limited the capacity of public transport vehicles. For instance; Milan and Barcelona have decided to reduce the maximum occupancy rates of public transport to $25 \%$ and $50 \%$ respectively, some cities in China and Istanbul and Ankara to 50\%, and some cities of Ireland and Portugal to $20 \%$ and $2 / 3$ respectively. In New South Wales and Australia, public transport capacity has been reduced to 12 and 32 passengers, respectively. In addition to these developments, serious increases are seen in the use of private vehicles that guarantee physical distance due to COVID-19, which is a global pandemic. During the pandemic in Budapest, the share of private vehicles in the travel modal split increased from $43 \%$ to $65 \%$. Since passengers in China see private transportation as a way to reduce the risk of infection, the share of private vehicles in the travel modal split has increased from $34 \%$ to $66 \%$. While the use of private vehicles in Istanbul was $15 \%$ before the pandemic, it increased to $54 \%$ during the pandemic period. In Ankara, which ranks first in private vehicle use, the share of private cars in the travel modal split has increased from $39 \%$ to $58 \%$. The sharp decline in public transport demand due to new physical distance behaviors and fear of COVID-19 transmission increases the use of private vehicles in cities, although it varies depending on the measures taken and practices applied. This situation poses a risk in global issues such as sustainability, accessibility and social equality in urban transportation. Because public transport is the backbone of the local economy. It makes urban mobility among socio-economic groups more accessible. It also ensures environmental justice. Therefore; studies should be carried out to increase the use of public transportation, it has to make a strong transition to the conditions after the pandemic and has to gain its the ability to fulfill its social roles.

The methodology in this study consists of 3 stages.

1. The measures and decisions taken by the government that restrict urban mobility in Ankara

2. Precautions and studies in public transportation due to COVID-19 pandemic in Ankara

3. Depending on these measures taken; when examining the change of public transport and private transport travels before and after the pandemic 
in Ankara, comparison of the travel modal split of March 32020 for the prepandemic period, the average of one working day of each month during the pandemic process, and for the day of April 16, 2021.

For the first time in Ankara, the share of private transportation has exceeded the share of public transportation in the travel modal split. Despite the decreasing mobility, it is seen that the increase in automobile use is due to the change in the preferences of the passengers using public transport. Global surveys show that one out of every three people hesitates to use public transport. If the effects of this change in travel habits throughout the pandemic period continue in the post-pandemic period, Ankara's urban transportation will reach an unsustainable point.

For this reason, the solutions to increase the use of public transportation in Ankara urban transportation are as follows:

- By investing in new services with advanced technology, studies that both protect public health and encourage the use of public transportation (ticketless mobile fare payment, traffic lights that reduce travel time with artificial intelligence, contactless fire measurement in public transport vehicles and stations, artificial intelligence techniques to provide mask detection).

- Enforcement of restrictions on automobile purchases.

Implementation of the "Trampe bicycle lift" in areas with high slopes.

\section{Kaynakça/References}

Arellena J., Marquez L. ve Cantillo V. (2020). COVID-19 Outbreak in Colombia: an analysis of its impacts on transport systems. Journal of Advanced Transportation, 1-16. https://doi.org/10.1155/2020/8867316

Bucsky, P. (2020). Modal share changes due to COVID-19: The case of Budapest. Transportation Research Interdisciplinary Perspectives, 8, 1-5.

CDC (Centers for Disease Control and Prevention) (2021). 14 Ekim 2021 tarihinde https:/www.cdc.gov/coronavirus/2019-ncov/prevent-getting-sick/howcovid-

spreads.html?CDC_AA_refVal=https $\% 3 \mathrm{~A} \% 2 \mathrm{~F} \% 2 \mathrm{Fwww} . c d c . g o v \% 2 \mathrm{Fcoronav}$ irus\%2F2019-ncov\%2Fabout\%2Findex.html adresinden erişilmiştir.

Cumhurbaşkanı Genelgesi No. 2020/4 (Konu: COVID-19 Kapsamında Kamu Çalışanlarına Yönelik İlave Tedbirler)

Cumhurbaşkanı Genelgesi No. 2020/8 (Konu: COVID-19 Kapsamında Kamu Kurum ve Kuruluşlarında Normalleşme ve Alınacak Tedbirler)

Cumhurbaşkanı Genelgesi No. 2020/11 (Konu: COVID-19 Kapsamında Kamu Çalışanlarına Yönelik Tedbirler) 
Cumhurbaşkanı Genelgesi No. 2021/8 (Konu: COVID-19 Kapsamında Kamu Çalışanlarına Yönelik Tedbirler)

Cumhurbaşkanı Genelgesi No. 2021/13 (Konu: COVID-19 Kapsamında Kamu Kurum ve Kuruluşlarında Normalleşme ve Alınacak Tedbirler)

De Vos, J. (2020). The effect of COVID-19 and subsequent social distancing on travel behavior. Transportation Research Interdisciplinary Perspectives, 5 .

Deloitte (2020). COVID-19 mobility in Belgium. 11 Ekim 2021 tarihinde https://www2.deloitte.com/content/dam/Deloitte/be/Documents/strategy/Mo bility_Covid\%20report_0805.pdf adresinden erişilmiştir.

Fishman, T., Kelkar, M. ve Schwartz, A. (2020). What are the most transformational trends in mobility today? 11 Ekim 2021 tarihinde https://www2.deloitte.com/us/en/insights/industry/publicsector/transportation-trends.html adresinden erişildi.

Gössling, S., Scott, D. ve Hall, C. M. (2020). Pandemics, tourism and global change: a rapid assessment of COVID-19. Journal of Sustainable Tourism, 29(1), 1-20.

İçişleri Bakanlığı (2020) Genelge No. 89780865-153-E.5768. 65 Yaş ve Üstü ile Kronik Rahatsızlığ Olanlara Sokağa Çıkma Yasağı

İçişleri Bakanlığı (2020b) Genelge No. 89780865-153-E.5823. Kent İçi Ulaşım Araçları (Minibüsler, Dolmuşlar, Halk Otobüsleri, Belediye Otobüsleri ve diğerleri) ile ilgili alınması gereken önlemler.

İçişleri Bakanlığı (2020c) Genelge No. 89780865-153-. Şehir Giriş/Çıkış Tedbirleri ve Yaş Sinırlaması

İçişleri Bakanlığ1 (2020d) Genelge No. 89780865-153-E.6484.10-12 Nisan 2020 Sokağa Çıkma Yasağı.

İçişleri Bakanlığı (2020e) Genelge No. 89780865-153-E.6879. 17-19 Nisan 2020 Sokağa Çıkma Yasağı.

İçişleri Bakanlığı (2020f) Genelge No. 89780865-153-E.7058. 23-24-25-26 Nisan 2020 Sokağa Çıkma Yasağı.

İçişleri Bakanlığ1 (2020g) Genelge No. 89780865-153-E.10077. 27-28 Haziran 2020 YKS Tedbirleri İstisnası ile Sokağa Çıkma Yasağı.

Koehl, A. (2020). Urban transport and COVID-19: challenges and prospects in lowand middle-income countries. Cities $\mathcal{E}$ Health, 1-6.

Marcucci, E., Lozzi, G., ve Valerio, G. (2020). COVID-19 and urban mobility: impacts and perspectives. 2 Ekim 2021 tarihinde https://research4committees.blog/2020/09/16/covid-19-and-urban-mobilityimpacts-and-perspectives/ adresinden erişilmiştir.

Moovit Toplu Taşıma Endeksi (2021). 16 Nisan 2021 tarihinde https://moovitapp.com/insights/tr/Moovit_Toplu_Ta\%C5\%9F\%C4\%B1ma_K ullan\%C4\%B1m_\%C4\%B0statistikleri_T\%C3\%BCrkiye_Istanbul-1563 adresinden erişilmiştir. 
Öcalır Akünal, E.V. ve Erol, S. (2016). Using cluster analysis to define the position of a developing country in global transportation services trade environment. Gazi University Journal of Science, 29(4), 751-767.

Terrill, M. (2020). Shame about the cars, but premier is right to be cautious about public transport. Sydney Morning Herald. https://www.smh.com.au/politics/nsw/shame-about-the-cars-but-premierisright-to-be-cautious-about-public-transport-20200518-p54txr.html.

Tirachini, A. ve Cats, O. (2020). COVID-19 and public transportation: current assessment, prospects, and research needs. Journal of Public Transportation, 22(1), 1.

UITP (2020). Public transport authorities and COVID-19: İmpact and response to a $\begin{array}{llll}\text { pandemic. } & 15 & \text { Nisan } & 2021\end{array}$ https://www.lek.com/sites/default/files/PDFs/COVID19-public-transportimpacts.pdf adresinden erişilmiştir.

UN (United Nations) (2002). Manual on statistics of international trade in services, Statistical papers series $M$ no. 86. Geneva, Luxembourg, New York, Paris, Washington, D.C.:Department of Economic and Social Affairs Statistics Division.

WHO (World Health Organization) (2020).14 Ekim 2021 tarihinde https://www.who.int/director-general/speeches/detail/who-director-generals-opening-remarks-at-the-media-briefing-on-covid-19---11-march-2020 adresinden erişilmiştir.

Yılmaz, C. (2020). Salgın başından itibaren ülkelerin aldığı önlemler. 11 Ekim 2021 tarihinde https:/www.dogrulukpayi.com/bulten/salginin-basindan-itibarenulkelerin-aldigi-onlemler-neler adresinden erişilmiştir.

Yücesan, B. ve Özkan, Ö. (2020). COVID-19 pandemi sürecinin sağlık yönetimi açısından değerlendirilmesi. Avrasya Sağlık Bilimleri Dergisi, 3(COVID-19), 134139. 